\title{
LLGL1 Gene
}

National Cancer Institute

\section{Source}

National Cancer Institute. LLGL1 Gene. NCI Thesaurus. Code C91766.

This gene is involved in cytoskeletal integrity. 